\title{
Analysis of Fish Demand in Sokoto Metropolis, Sokoto, Nigeria
}

\author{
M. Dalhatu* and A. L. Ala** \\ *Department of Agriculture, The Polytechnic of Sokoto State, Nigeria. \\ **Department of Agric. Economics and Extension, Usmanu Danfodiyo University Sokoto, \\ Nigeria.
}

\begin{abstract}
This study analyzed fish demand in Sokoto metropolis. Primary data were collected from a total of 180 fish consumers using simple random sampling. Data were collected on household consumption activities between October and December 2007. The Data were analyzed using descriptive statistics and multiple regression analysis. The results of the multiple regression analysis revealed a coefficient of determination $\left(\mathrm{R}^{2}\right)$ of 0.699 and F-value of 27.406 which was statistically significant at $\mathrm{P}<0.01$. It was evident from the study that the higher the income level of the Respondents, the higher the expenditure on fish and fish demand also increases as household size and level of education increases. It was also revealed that disposable income, price of substitutes, level of education and household size positively influenced fish demand while price of fish influenced fish demand negatively. Major constraints to fish demand in the study area include insufficient number of fish markets, low level of consumer's income and small number of fish farmers among others.
\end{abstract}

Key words: Demand, Fish, Analysis, Sokoto Metropolis.

\section{INTRODUCTION}

In spite of the numerous natural and human resources at her disposal, Nigeria still remains amongst the least consumers of protein in Africa (Ajana, 1999). Abiodun (2001) observed that the protein intake by Nigeria is about $53.8 \mathrm{~g}$ with only 6.0 to $8.4 \mathrm{~g} / \mathrm{head} /$ day of animal origin. FAO (1991) pointed out that protein for human consumption comes from two main sources, namely: plants and animals. Plant proteins are deficient in certain essential amino acids notably methionine, tryptophan and lysine which are essential for healthy growth. However, animal proteins are rich in these amino acids and are therefore described as first class or good quality protein (Lamorde, 1998). In recent years, increased knowledge and awareness of human requirement for healthy growth have focused increasing attention on the unique roles of livestock and fisheries resources in human development (CBN, 2002). Lamorde (1998) stressed that protein and calorie malnutrition or shortage in ingested foods resultantly impedes health, working efficiency, productivity and overall economic progress. In the developing countries, fish is a highly acceptable food that supplies as much as 40 percent of all animal protein available to the countries where fish is the main source of animal protein (Edgerton and Assarsson, 1998). According to Alexandratos (2000), the ever increasing share of fish in animal protein intake and total protein supply implies that fish has become more and more important in people's diet.

Over the past 15 years, fish has enjoyed an explosive increase in demand around the world; a demand that has also boosted its price (Amao et al., 2006). The authors indicated that there is heightened awareness in the developed world of the nutritional and health benefits of fish products which are low in fat and calories and high in protein, vitamins, minerals and polyunsaturated fatty acids. FAO (1991) predicted an increase in demand for fish, pointing that the majority of this increase will result from expected economic development, population growth and changes in food habits. Supply from capture fisheries is expected to remain constant or even begin to decline (FAO, 2001). Furthermore, fish supply from capture fisheries in most countries is believed to have 
reached or to be close to maximum sustainable yield.

\section{MATERIALS AND METHODS}

Simple random sampling was used to select 12 out of the 23 electoral wards that made up Sokoto metropolis. In these wards, fish consumers were targeted as the population, 35 fish consuming households in each of the 12 electoral wards and 15 households were randomly selected from the 35 households in each ward. Therefore, a total of 180 respondents were selected for the study. The cross-sectional data for the study were collected from primary and secondary sources within a period of six months. The primary data were collected through administration of questionnaires which were designed to contain close and open ended questions. Descriptive statistics and multiple regression analysis were used to analyze the data.

The Regression Model: Multiple regression analysis is a model useful for estimating the relationship between dependent and independent variables. A multiple regression model containing a mixture of quantitative and qualitative variables, otherwise known as the analysis of covariance model, was used in identifying factors that affect fish demand expenditure.

The demand function that was estimated is specified generally as:

$\mathrm{Y}=\mathrm{f}\left(\mathrm{X}_{1}, \mathrm{X}_{2}, \mathrm{X}_{3}, \mathrm{X}_{4}, \mathrm{X}_{5}, \mathrm{X}_{6}, \mathrm{X}_{7}, \mathrm{D}_{2}, \mathrm{D}_{3}, \mathrm{D}_{4}\right.$,

$\mu)$

Where:

$\mathrm{Y}=$ Monthly demand expenditure on fish

(Naira)

$\mathrm{X}_{1}=$ Retail price of fish in naira $(\mathrm{kg})$

$\mathrm{X}_{2}=$ Retail price of beef in naira $(\mathrm{kg})$

$\mathrm{X}_{3}=$ Retail price of chicken in naira $(\mathrm{kg})$

$\mathrm{X}_{4}=$ Retail price of goat meat in naira $(\mathrm{kg})$

$\mathrm{X}_{5}=$ Monthly disposable income (Naira)

$\mathrm{X}_{6}=$ Household size (No.)

$\mathrm{X}_{7}=$ Level of education (years)

$D_{1}=1$ if form of fish is fresh, $O$ otherwise.

$\mathrm{D}_{2}=1$ if form of fish is smoked, $\mathrm{O}$ otherwise.

$\mathrm{D}_{3}=1$ if form of fish is fried, $\mathrm{O}$ otherwise.

$\mu=$ Random error term

$\mathrm{f}=$ Functional notation .
The above demand function was estimated using four functional forms: linear, semi-logs, (linear$\log$ and log-linear) and Cobb-Douglas (double$\log$ ). The lead equation from the four functional forms was chosen based on the agreement with the a-priori expectation of the parameter estimates and statistical tests such as the coefficient of determination, $\left(\mathrm{R}^{2}\right)$.

Table 1: Distribution of fish consumers based on socio-demographic characteristics

\begin{tabular}{lll}
\hline Socio-economic characteristics & F & \% \\
\hline Educational level & & \\
Non formal education & 43 & 24 \\
Primary education & 49 & 27 \\
Secondary education & 43 & 24 \\
Tertiary education & 45 & 25 \\
Total & $\mathbf{1 8 0}$ & $\mathbf{1 0 0}$ \\
Household size & & \\
1-4 & 32 & 18 \\
5-8 & 75 & 42 \\
9-12 & 60 & 33 \\
13 and above & 13 & 7 \\
Total & $\mathbf{1 8 0}$ & $\mathbf{1 0 0}$ \\
Primary Occupation & & \\
Farming & 22 & 12 \\
Trading & 8 & 27 \\
Civil Service & 87 & 48 \\
Artisan & 20 & 11 \\
Others & 3 & 2 \\
Total & $\mathbf{1 8 0}$ & $\mathbf{1 0 0}$ \\
\hline * Others include motorcycle and taxi drivers & \\
F = Frequency & & \\
Occupation: Table & &
\end{tabular}

Occupation: Table 1 also reveals that reasonable percentages (48\%) of the fish consumers are civil servants. Occupation is a variable that is related to income (Ahmed, 1997). However, it was reported that a large proportion of people of Sokoto State working as civil servants are of the junior cadre due to the fact that only few of them had tertiary education (SOSG, 2007).

Income groups: The major factor that closely affects fish consumption is disposable income of individual households (Ye, 1996). Therefore, the income level of household head is expected to be a major determinant of food and fish demand and the nutritional status of the household in general. Table 4 indicates that $44 \%, 32 \%$ and $24 \%$ of the respondents were in low, medium and high income groups, respectively. The 
results further indicate that there were more fish consumers in the low income group than medium and high income groups. Table 3 showed the results of the Cobb-Douglas functional form, the coefficient of multiple determinations $\left(\mathrm{R}^{2}\right)$ was found to be 0.699 implying that $69.9 \%$ of the variation in fish demand expenditure was explained by variations in the explanatory variables included in the model. The F-value was 27.406, which was statistically significant at $\mathrm{P}<0.01$. It implies that the joint influence of all the explanatory variables on fish demand was quite strong.

Table 2: Distribution of fish consumers based on monthly income

\begin{tabular}{lll}
\hline Income groups & F & \% \\
\hline Low & 79 & 44 \\
Medium & 58 & 32 \\
High & 43 & 24 \\
Total & $\mathbf{1 8 0}$ & $\mathbf{1 0 0}$
\end{tabular}

$\mathrm{F}=$ Frequency

Low $=$ Below 14,999 Naira/month

Medium =15,000-19,999 Naira/month

High =Above 20,000 Naira/month

The regression coefficient for price of fish $\left(\mathrm{X}_{1}\right)$ was -0.026 , implying that an increase in own price of fish by $1 \%$, holding other factors constant, decreases the monthly expenditure for fish by $0.026 \%$. The regression coefficient for price of fish $\left(\mathrm{X}_{1}\right)$ exhibits its expected negative sign which implies that the lower the price of fish, the more the quantity demanded. According to Omu (2000), consumers will arrange consumption in such a way that the marginal utility derived from each commodity is proportional to price. Similarly, Ajana (1999), in his study, found that relative small changes in food prices affect the ability of consumers to meet basic nutritional requirements.

The results in Table 3 also showed that prices of beef $\left(X_{2}\right)$, chicken $\left(X_{3}\right)$, and goat meat $\left(X_{4}\right)$ with coefficients of $0.101,0.389$ and 0.015 , respectively, had a positive relationship with fish demand expenditure. This positive sign is consistent with the apriori expectation which implies that prices of substitutes were directly related to fish demand expenditure. In the study of economics of fish demand in Lagos State,
Amao et al. (2006) found that the fish consumers with income less than $\mathrm{N} 10,000$ and income between $\mathrm{N} 10,000$ to $\mathrm{N} 20,000$ spent more on substitutes than fish. The authors further pointed out that this might be due to the relative cheapness of the substitutes in the study area.

From the results in Table 3, the monthly disposable income $\left(\mathrm{X}_{5}\right)$ of the consumer had its expected positive sign, with regression coefficient of 0.075 . The positive sign indicates that disposable income $\left(\mathrm{X}_{5}\right)$ is directly related to fish demand expenditure. The positive income coefficient also suggests that fish is a normal good in the study area. Ye (1996) pointed out that with increased disposable incomes, peoples' purchasing power is then expected to rise and more money will be expended on food. This is also in line with Delgado et al., (2003) who claimed that the demand for fish products at the household level, as at the national level, is quite responsive to income.

The regression coefficient of household size $\left(\mathrm{X}_{6}\right)$ was 1.060 . It was positive and shows that an increase in the household size by $1 \%$, holding other factors constant, will increase monthly fish demand expenditure by $1.060 \%$. The larger the household size, the more the expenditure on fish. This is in conformity with the findings of Joseph (2004) who found that increase in household size lead to increase in fish demand expenditure.

It could be noticed, from Table 3, that the level of education of the consumer $\left(\mathrm{X}_{7}\right)$ showed a positive relationship with fish demand expenditure, implying that an increase in the level of education of a consumer leads to an increase in fish demand expenditure. This could be due to more awareness of the nutritive value of fish as a good protein source. This is supported by Amao et al., (2006) that consumption of fish has to do with knowing the importance of protein and the best source of it through education. Also in Table 3 using frozen fish as a base for comparison of preferred forms of fish, shows that the regression coefficients for 
fresh fish $\left(\mathrm{D}_{1}\right)$, smoked fish $\left(\mathrm{D}_{2}\right)$ and fried fish $\left(\mathrm{D}_{3}\right)$ were 6.121, 22.072 and -0.930, respectively. It implies that presenting fish in fresh form, instead of frozen form, would increase fish demand expenditure by $6.121 \%$. This may be due to the fact that fresh fish is more palatable than frozen fish as indicated by Joseph (2004) that even if fish is frozen immediately after being caught, there is apparently a loss in flavor, although there are advantages to freezing, such as storage and transportation efficiency.
The results also revealed that presenting fish in smoked instead of frozen form would increase fish demand expenditure by $22.072 \%$. This is in line with Amao et al. (2006) who revealed that presenting fish in smoked instead of frozen form would increase fish demand expenditure. The results also revealed that presenting fish in fried instead of frozen from would reduce fish demand expenditure by 0.930 . This agrees with both Amao et al .(2006) and Joseph (2004).

Table 3: Results of the Cobb-Douglas functional form on fish demand

\begin{tabular}{|c|c|c|}
\hline Predictor & Regression coefficient & $\overline{t-\text { ratio }}$ \\
\hline Constant term & $0.530 * * *$ & 0.220 \\
\hline Price of fish & $-0.026 * *$ & -0.084 \\
\hline Price of beef & $0.101 *$ & 2.350 \\
\hline Price of chicken (X3) & $0.389 \mathrm{~ns}$ & 0.010 \\
\hline Price of goat meat $(\mathrm{X} 4)$ & $0.015 \mathrm{~ns}$ & 0.452 \\
\hline Disposable income (X5) & $0.075 * * *$ & 1.701 \\
\hline Household size & $1.060 * * *$ & 9.016 \\
\hline Level of education (X7) & $3.039^{* *}$ & 0.122 \\
\hline Fresh fish & $6.121 \mathrm{~ns}$ & 0.084 \\
\hline Smoked fish & $22.072 \mathrm{~ns}$ & 0.461 \\
\hline Fried fish & $-0.930 \mathrm{~ns}$ & -0.904 \\
\hline $\mathrm{R} 2=0.699$ & F- ratio $=27.406 * * *$ & \\
\hline
\end{tabular}

Own price elasticity of fish: The coefficient of each variable from the selected Cobb-Douglas functional form, constitutes the respective elasticity of demand with respect to each variable (Gujarati, 2001).

The price elasticity of demand is the relative responsiveness of quantity demanded to changes in commodity prices (Asche and Bjorndal, 1999). From Table 3, the own price elasticity was found to be -0.026 , which was significant at $\mathrm{P}<0.05$. Price of fish exhibited its expected negative sign showing an inverse relationship between fish and its price, implying that increase in price of fish leads to decrease in fish demand.

Cross-price elasticity: The cross-price elasticity of demand measures the relative responsiveness of quantity demanded of a particular commodity to changes in the price of a related commodity (Asche and Bjorndal, 1999). The authors stressed that it provides a measure of the extent to which commodities are related to each other. Here, commodities are related as substitutes or complements depending on the sign of the value of cross-price elasticity. Positive and negative elasticities imply that commodities are substitutes and complements, respectively. From Table 3, the cross price elasticities for beef, chicken and goat meat was $0.101,0.389$ and 0.015 , respectively. The positive signs confirm that fish and other animal protein sources are substitutes as expected and not complements. If they were complements, the signs of the cross price elasticities will be negative; meaning that an increase in the price of fish cuts down its 
consumption and consequently the consumption of other commodities. This does not conform to Joseph (2004) who found a complementary relationship between fish and other animal protein sources.

Income elasticity: The income elasticity of demand is the relative responsiveness of quantity demanded to changes in income (Adamu, 1996). From Table 3, income elasticity was found to be 0.075 . Since the value of income elasticity is positive, it suggests that fish is a normal good in the study area and that people will prefer taking fish or increase their consumption of it when there is increase in income. This finding is similar to that of Amao et al., (2006) and Joseph (2004).

Constraints to fish demand: The constraints faced by the fish consumers are presented in Table 4. The Table showed the distribution of fish consumers according to constraints to fish demand in the study area. Some of the fish consumers (29\%) believed that the most important constraint facing fish demand is insufficient number of fish markets around Sokoto metropolis. As a result, people have to go long distances in order to buy fish, especially fresh one. Tabor (1990) asserted that part of the problems militating against fish demand is inefficient marketing system. Other Respondents $(17 \%)$ pointed out that there is low supply of fish especially fresh one. This means that even if one reaches the fish market, the supply of different varieties of fish at a given time is not always adequate. As a result, consumers may be forced to buy varieties of fish that they do not actually prefer.

Table 4: Distribution of the fish consumers according to constraints faced by fish demand

\begin{tabular}{lll}
\hline Constraints & Frequency & Percentage \\
\hline Insufficient number of fish markets & 52 & 29 \\
Low supply & 30 & 17 \\
Rapid fish spoilage & 36 & 20 \\
High prices & 29 & 16 \\
Low level of consumers' income & 41 & 23 \\
Small number of fish farmers & 32 & 18 \\
Total & $218^{*}$ & $123^{*}$ \\
\hline
\end{tabular}

*Multiple responses

Other constraint to fish demand by some consumers $(20 \%)$ is rapid fish spoilage. They pointed that due to erratic power supply, they cannot buy large quantities of fish for fear spoilage; therefore, they resort to buying only the quantity they need at a given time.

Sixteen percent of the consumers (16\%) identified high prices of fresh and smoked fish. This may be due to insufficient supply of the commodity regularly into the market. It may also lead to low demand of fish by some of the Respondents especially the low income group. Only 23\% of the Respondents identified low level of income as being the reason why there is low demand for fish. They maintained that due to economic condition of consumers especially the low income category, fish is sometimes unaffordable. Other Respondents (18\%) indicated that there is relatively small number of fish farmers which consequently lead to low supply of the commodity into the market. Supply is therefore left largely to capture fisheries from inland waters and which is not enough for the quantity demanded in Sokoto metropolis.

Conclusion: The study showed that price of fish, disposable income, household size and level of education were major determinants of consumer demand for fish in the study area, while factors such as price of substitutes and forms of fish were secondary determinants.

\section{REFERENCES}

Abiodun, W. (2001). Demand for beef: A case study of Ibadan city. An Unpublished B. Sc. Project, Department of Agric Economics, University of Ibadan. $58 \mathrm{Pp}$. 
Adamu, S. O. (1996). Expenditure elasticities of demand for household consumer goods.

Nig. J. Econs. Social Stud. 8 (3): 35-42.

Ahmed, A. (1997). Fisheries Economics and Trade. In: Asche, F. and Bjorndal, T. (1999). Demand elasticities for fish: A review. Globefish special series No 9. Rome: Food and Agriculture Organisation of the United Nations. Pp 82-95.

Ajana, A. M. (1999). Overview of Highlight and Problems of Fisheries Extension in Nigeria. Paper Presented in Ibadan at NIOMER During a Workshop on Improvement of Fisheries Extension in Nigeria $12^{\text {th }}-16^{\text {th }}$ March 1999.

Alexandratos, N. (2000). World Agriculture towards 2010: An FAO Study. Rome and Chichester, U.K. Food and Agriculture Organization of the United Nations and John Wiley. Pp 34-41.

Amao, J. O., Oluwatayo I. B. and Osuntope F. K. (2006). Economics of Fish Demands in Lagos State, Nigeria. Journal of Human Ecology, 19(1): 25-30.

Asche, F. and Bjorndal, T. (1999). Demand elasticities for fish: A review. Globefish special series No 9. Rome: Food and Agriculture Organisation of the United Nations. Pp 82-95.

Central Bank of Nigeria (2002). Domestic Consumption of Animal Protein. Annual reports of the Central Bank of Nigeria. 23pp.

Delgado C. L., Wada, N. Rosegrant M. W. and Ahmed M. (2003). Fish to 2020. Supply and Demand in Changing Global Markets. Wellington, New Zealand. Pp 29-44.
Edgerton D. and Assarsson B. (1998). The Econometrics of Demand Systems: With Applications to Food Demand in Nordic Countries, Boston: Kluwer academic Press. Pp 34-39.

Food and Agriculture Organization (1991). Fish for Food and Development. FAO Annual Publication, Rome. 58 pp.

Gujarati, D. N. (2001). Basic Econometrics. Fourth Edition, New York. McGraw Hill, $685 \mathrm{pp}$.

Joseph (2004): An analysis of fish demand in two urban centers in Ogun State, Nigeria. An unpublished M.Sc. thesis submitted to the Department of Agricultural Economics and Extension, Usmanu Danfodiyo University Sokoto, Nigeria.

Lamorde, A. G. (1998). Scenario building for the Nigeria Livestock Industry in The $21^{\text {st }}$ century. A paper presented at the silver anniversary conference of the NSAP, 1998 held at the Gateway hotel, Abeokuta Nigeria. $17^{\text {th }}-23^{\text {rd }}$ October 1998.

Omu, J. U. (2000). Economics: An African Perspective. John West publication Ltd Nigeria. 327 pp.

Sokoto State Government (2007). Strategies for poverty reduction in Sokoto State. A handbook published by the Budget and Economic Planning, Sokoto State. 43pp.

Tabor, L. U. (1990). Fish Marketing Plan. Proceedings of the tenth annual conference of the fisheries society of Nigeria. pp 45-47.

Ye, Y. (1996). Market demand and supply potential of chineese fish products. Marine Resource Economics. 11 (2): 115-118. 